\title{
The East River Community Observatory Data Collection: Diverse, multiscale data from a mountainous watershed in the East River, Colorado
}

\author{
Zarine Kakalia ${ }^{1}$, Charuleka Varadharajan ${ }^{1}$, Erek Alper $^{2}$, Eoin Brodie ${ }^{1}$, Madison Burrus ${ }^{1}$, \\ Rosemary Carroll ${ }^{3}$, Danielle Christianson ${ }^{1}$, Valerie Hendrix ${ }^{1}$, Matthew Henderson ${ }^{1}$, Susan \\ Hubbard $^{1,1}$, Douglas Johnson ${ }^{2}$, Roelof Versteeg ${ }^{2}$, Kenneth Williams ${ }^{4}$, and Deborah \\ Agarwal $^{1}$ \\ ${ }^{1}$ Lawrence Berkeley National Laboratory \\ ${ }^{2}$ Subsurface Insights LLC \\ ${ }^{3}$ Desert Research Institute \\ ${ }^{4}$ E O Lawrence Berkeley National Laboratory
}

October 1, 2020

\begin{abstract}
The U.S. Department of Energy's (DOE) East River community observatory (ER) in the Upper Colorado River Basin was established in 2015 as a representative mountainous, snow-dominated watershed to study hydrobiogeochemical responses to hydrological perturbations in headwater systems. Led by the Watershed Function Science Focus Area (SFA), the ER has both long-term and spatially-extensive observations paired with experimental campaigns. The Watershed Function SFA, led by Berkeley Laboratory, includes researchers from over 30 organizations who conduct cross-disciplinary process-based investigations and mechanistic modeling of watershed behavior in the ER. The data generated at the ER are extremely heterogeneous, and include hydrological, biogeochemical, climate, vegetation, geological, remote sensing, and model data that together comprise an unprecedented collection of data and value-added products within a mountainous watershed, across multiple spatiotemporal scales, compartments, and life zones. Within 5 years of data collection, these datasets have already revealed insights into numerous aspects of watershed function such as factors influencing snow accumulation and melt timing, water balance partitioning, and impacts of floodplain biogeochemistry and hillslope ecohydrology on riverine geochemical exports. Data generated by the SFA are managed and curated through its Data Management Framework. The SFA has an open data policy, and over sixty ER datasets are publicly available through relevant data repositories. A public interactive map of data collection sites run by the SFA is available to inform the broader community about SFA field activities. Here, we describe the ER and the SFA measurement network, present the public data collection generated by the SFA and partner institutions, and highlight the value of collecting multidisciplinary multiscale measurements in representative catchment observatories.
\end{abstract}

\section{Abstract}

The U.S. Department of Energy's (DOE) East River community observatory (ER) in the Upper Colorado River Basin was established in 2015 as a representative mountainous, snow-dominated watershed to study hydrobiogeochemical responses to hydrological perturbations in headwater systems. Led by the Watershed Function Science Focus Area (SFA), the ER has both long-term and spatially-extensive observations paired with experimental campaigns. The Watershed Function SFA, led by Berkeley Laboratory, includes researchers from over 30 organizations who conduct cross-disciplinary process-based investigations and mechanistic modeling of watershed behavior in the ER. The data generated at the ER are extremely heterogeneous, 
and include hydrological, biogeochemical, climate, vegetation, geological, remote sensing, and model data that together comprise an unprecedented collection of data and value-added products within a mountainous watershed, across multiple spatiotemporal scales, compartments, and life zones. Within 5 years of data collection, these datasets have already revealed insights into numerous aspects of watershed function such as factors influencing snow accumulation and melt timing, water balance partitioning, and impacts of floodplain biogeochemistry and hillslope ecohydrology on riverine geochemical exports. Data generated by the SFA are managed and curated through its Data Management Framework. The SFA has an open data policy, and over sixty ER datasets are publicly available through relevant data repositories. A public interactive map of data collection sites run by the SFA is available to inform the broader community about SFA field activities. Here, we describe the ER and the SFA measurement network, present the public data collection generated by the SFA and partner institutions, and highlight the value of collecting multidisciplinary multiscale measurements in representative catchment observatories.

\section{Site Description}

The East River community observatory (ER) in the Upper Colorado Basin, United States $\left(39.033^{\circ} \mathrm{N} 107.12^{\circ}\right.$ $\mathrm{W}, 38.83^{\circ} \mathrm{N} 106.88^{\circ} \mathrm{W}$ ) is a 300 square kilometer headwater catchment representative of watersheds in the Rocky mountains of the Western United States (Hubbard et al., 2018). Since 2015, the ER has been the primary field site for the U.S. Department of Energy's Watershed Function Scientific Focus Area (SFA; http://watershed.lbl.gov), and now serves as a community testbed for over 30 collaborating institutions that collectively aim to understand the impacts of perturbations, such as drought and early snowmelt, on the hydrobiogeochemical dynamics of mountainous, headwater catchments at seasonal to decadal timescales. The ER spans first-order mountain streams and meandering floodplains across four drainages - the East River, Washington Gulch, Slate River, and Coal Creek (Figure 1a). The ER lithology consists of igneous formations intruding into carbon-rich marine shale in the Mancos Formation, as well as sedimentary strata grading older (Permian) to younger (Tertiary) as one moves east to west across the ER domain with pockets of significant mineralization (Carroll et al., 2018; Gaskill, 1991). In addition to geologic variability, the ER is characterized by steep elevation, hydrologic and vegetation gradients along floodplain, montane, subalpine, and alpine life zones, which makes it an ideal location to understand how different mountain subsystems contribute to overall watershed behavior.

\section{Measurements and field infrastructure}

The SFA and collaborators have collected extensive sample- and sensor-based measurements at several locations across the East River and adjacent drainages (Figure 1a). Regions of particular emphasis include "SFA-intensive" sites located within representative meanders and a hillslope in a lower montane (Pumphouse) subregion of the pristine East River drainage basin, where several cross-disciplinary, co-located measurements are being conducted (Figure 1b). Additional "satellite" sites, targeting specific research questions are located near the Brush Creek confluence floodplain, an elevation gradient of research meadows along Washington Gulch and on the flanks of Cinnamon Mountain and Mount Baldy, Snodgrass Mountain, and mining-impacted sites in both Coal Creek and the Redwell Basin.

The ER instrumentation network maintained by the SFA and collaborators includes 15 stream-gauging and water quality stations used to obtain paired concentration-discharge measurements, 6 weather stations with soil moisture and temperature probes, 18 instrumented groundwater wells (e.g Figure 2a-2c), and about 40 piezometers, $\sim 15$ ecohydrological sensor stations, and $\sim 40$ digital phenocam locations (Varadharajan et al. 2020). An eddy flux tower is maintained in the East River floodplain by the National Center for Atmospheric Research (NCAR). Extensive measurements of depth-resolved snow density, snow water equivalent and water isotopes as well as whole-pit chemistry, snowmelt water isotopes, rain chemistry and water isotopes have been conducted over multiple years to inform stream water source (Fang et al., 2019). Snowmelt manipulation experiments in vegetation plots in different mountain life zones were used to study the impacts of snowmelt timing on vegetation phenology. Metagenomic analyses of microbial communities have been conducted for soils and sediments representing various locations across the floodplain meanders and lower montane hillslopes that contribute water and various elements to the river (Lavy et al., 2020; Matheus Carnevali et al., 2020; 
Sorensen et al., 2020). As a result, and with watershed-scale surveys in progress, the East River watershed in Colorado is fast becoming the most genomically characterized high-elevation watershed in the world, with over 5,000 metagenome-assembled genomes to date enabled by DOE JGI-CSP and FICUS awards. In addition, several multi-institutional remote sensing campaigns have been conducted at the ER which include a 2015 Light Detection and Ranging (LiDAR) survey led by the SFA (Wainwright \& Williams, 2017), Airborne Snow Observatory (ASO) flights by the National Aeronautics and Space Administration's Joint Propulsion Laboratory (NASA JPL) in 2016, 2018 and 2019 (Painter et al., 2016), a 2017 USGS Airborne Electromagnetic survey, and a 2018 National Ecological Observation Network (NEON) hyperspectral survey paired with an extensive ground-based campaign conducted in coordination with Stanford University (Chadwick et al., 2020). In 2021, a two-year deployment of the DOE's Atmospheric Radiation Measurement (ARM) Program mobile Surface Atmosphere Integrated Field Laboratory (SAIL) will use more than three dozen instruments to collect a suite of meteorology, clouds, aerosol and other atmospheric measurements in the ER (http://sail.lbl.gov). The SFA's ER measurement locations are viewable through a public, user-friendly field information portal (https://wfsfa-data.lbl.gov/watershed/).

The ER watershed also has significant infrastructure maintained by several federal, state, and local agencies that have different data systems (some of these are indicated in Figure 1a). Notably, the Rocky Mountain Biological Laboratory (RMBL, https://www.rmbl.org/) is situated in the townsite of Gothic, and has over 90 years of data collection activities in the watershed. Snow measurements and associated meteorological data are available from the National Resources Conservation Service (NRCS) snow Telemetry (SNOTEL) sites 'Butte' and 'Schofield Pass', Crested Butte Cooperative Observer Network (COOP), and a number of Weather Underground stations. The USGS maintains gaging stations and collects water quality measurements across the East-Taylor watersheds, and makes the data available through NWIS (HUC: 14020001). Additional water quality data are available from the National Water Quality Portal, which includes measurements by the U.S. Environmental Protection Agency (EPA), Colorado Department of Public Health and Environment (CDPHE), and local groups including the Coal Creek Watershed Coalition and the Rivers of Colorado Water Watch. The EPA also maintains a National Atmospheric Deposition Program (NADP) Colorado Clean Air Status and Trends Network (CASTNET) station at Gothic.

\section{Overview of ER Datasets and Research Themes}

The Watershed Function SFA and its collaborators generate vastly diverse, multiscale datasets at the ER including hydrological, (bio)geochemical, climate, vegetation, geophysical, microbiological, remote sensing, and model data. Additionally, several model datasets are generated from numerical simulations of different watershed subsystems and their aggregated behavior. Detailed descriptions of the data types, data variables collected, and methods used are listed in Table 1. The most common publicly available data types from the ER during 2015-2020 are biogeochemistry and hydrology data (Figure 3).

The simultaneous collection of these data types across the watershed allows researchers across institutions to share knowledge and draw conclusions. Examples of research topics that these data were collected to address include correlations of hydrologic data with variation in climate and microclimate; effects of snow accumulation and melt timing on vegetation, microbial and watershed function; stream gas exchange rates, groundwater and surface water interactions, biogeochemical hotspots and hydrodynamics; cycling and sourcing of metal nutrients by plants, nitrogen release dynamics from shale bedrock; sources of elemental contributions to the East River and weathering processes impact on river water; solute concentration responses and water partitioning to quantify seasonal stream water; and more broadly an aggregated understanding of watershed hydrobiogeochemical processes given their variation over space and different watershed functional zones and compartments.

\section{Data Policy, Curation Process, and Availability}

The SFA has a Data Management Framework component that provides services and infrastructure to support the project's data lifecycle. The framework comprises systems, workflows and scripts to acquire and store data in a queryable database, conduct $\mathrm{QA} / \mathrm{QC}$, integrate project data with external data for real-time 
queries, discover and download data, and to publish data with digital object identifiers (DOIs) in the DOE's Environmental Systems Science Data Infrastructure for a Virtual Ecosystem (ESS-DIVE) repository (Varadharajan et al., 2019). Additionally, the SFA has developed an integrated field-data workflow to acquire critical metadata from these diverse data streams, and to manage data at each stage of the scientific process. The field-data workflow outlines guidelines for managing metadata and identifiers for field locations, samples, sensors, and data package creation and publication. While developed by the SFA, the workflow is available to other collaborating organizations, and is built based on community feedback and established data management best practices.

The SFA has an open data policy where project-generated data are made publicly available following the U.S. Department of Energy's guidelines (https://watershed.lbl.gov/data/data-policy/). Several datasets generated by the SFA and collaborators at the ER are publicly available in online repositories, including ESS-DIVE, NCBI, United States Geological Survey (USGS), NASA DAAC: National Snow and Ice Data Center, Figshare, and HydroShare (Table 2). The SFA alone has 36 public datasets with associated metadata available on ESS-DIVE that include many of the long-term monitoring and spatially-extensive remote sensing and associated ground campaign datasets. A collection of data packages generated across institutions at the ER can be accessed on ESS-DIVE through the East River watershed portal (https://data.ess-dive.lbl.gov/portals/eastriver-watershed). The data are typically licenced under Creative Commons by Attribution (CC-By4.0) or Creative Commons Public Domain (CC0) usage policies. Large datasets such as the remote sensing or model products are stored and distributed through public data transfer nodes on the DOE's National Energy Scientific Computing Center (NERSC).

\section{Scientific Impact of ER Datasets}

The multidisciplinary data from the ER have already advanced significant understanding of hydrological processes in mountainous catchments, and they have been used in numerous publications of which a select few are highlighted here. For example by combining measurements of river, rain, groundwater and snow chemistry, stream discharge, remote sensing (LIDAR, ASO), Carroll et al. $(2018,2019)$ found that groundwater recharge, an important contributor to streamflow, is dependent on elevation and vegetation and increases in higher elevations, such as the upper subalpine zone where there is greater snow accumulation and lower canopy cover. Through analyses of data on groundwater chemistry, water table depth, and rock mineralogy, Wan et al. (2019) found that the seasonal water table depth determines the weathering zone and weathering front in sedimentary bedrock, and that the Mancos shale can be a significant contributor to river nitrogen exports. Combining snow measurements with metagenome analysis, (Sorensen et al., 2020) found that snowmelt triggers a pulse of nitrogen in hillslope soils concomitant with a collapse in microbial biomass, and changes in microbial community composition. Using model simulations of floodplain meanders and regions of hyporheic exchange, Dwivedi et al. $(2017,2018)$ found these subsystems exert critical controls on nitrogen cycling and other solute exports to the river. These findings, and others from the ER community, highlight the value of designing multidisciplinary watershed observatories using open science by design principles, and publishing data generated in open, public repositories (Stegen et al., 2019).

\section{Data Availability Statement}

The data that support the findings of this study are openly available in several repositories as listed in Table 2 .

\section{Acknowledgements}

This research is supported as part of the Watershed Function Scientific Focus Area funded by the U.S. Department of Energy, Office of Science, Office of Biological and Environmental Research under Contract No. DE-AC02-05CH11231. This research used resources of the National Energy Research Scientific Computing Center (NERSC) and the U.S. Department of Energy's Joint Genome Institute (JGI), which are U.S. Department of Energy Office of Science user facilities operated under Contract No. DE-AC02-05CH11231. Support to Subsurface Insights for development of some of the core abilities used here under awards DE-SC0009732 and DE-SC0018447 is gratefully acknowledged. We also acknowledge the members of the Watershed SFA 
community who provided information about their datasets for this paper, including Erica Woodburn, Max Berkelhammer, Rich Wanty, Curtis Beutler, Heidi Steltzer, Amanda Henderson, Brian Enquist, Baptiste Dafflon, Li Li, Qina Yan, Kamini Singha, Martin Briggs, Reed Maxwell, David Gochis, Anna Ryken, Bhavna Arora, Sebastian Uhlemann, Michael Wilkins, Amelia Nelson, Ulas Karaoz, Janice Brahney, Yuxin Wu, Dana Chadwick, Boris Faybishenko, John Christensen, Wendy Brown, Nick Bouskill, Pat Sorensen, Jiancong Chen, Jiamin Wan, James St. Clair, Savannah (Bryant) Scott, Matthew Winnick, Anna Chovanes, Xiaoqin Wu, Ate Visser, Mark Raleigh, Jeffrey Deems, Joel Rowland, Michelle Newcomer, and Mariah Carbone.

\section{FIGURES}

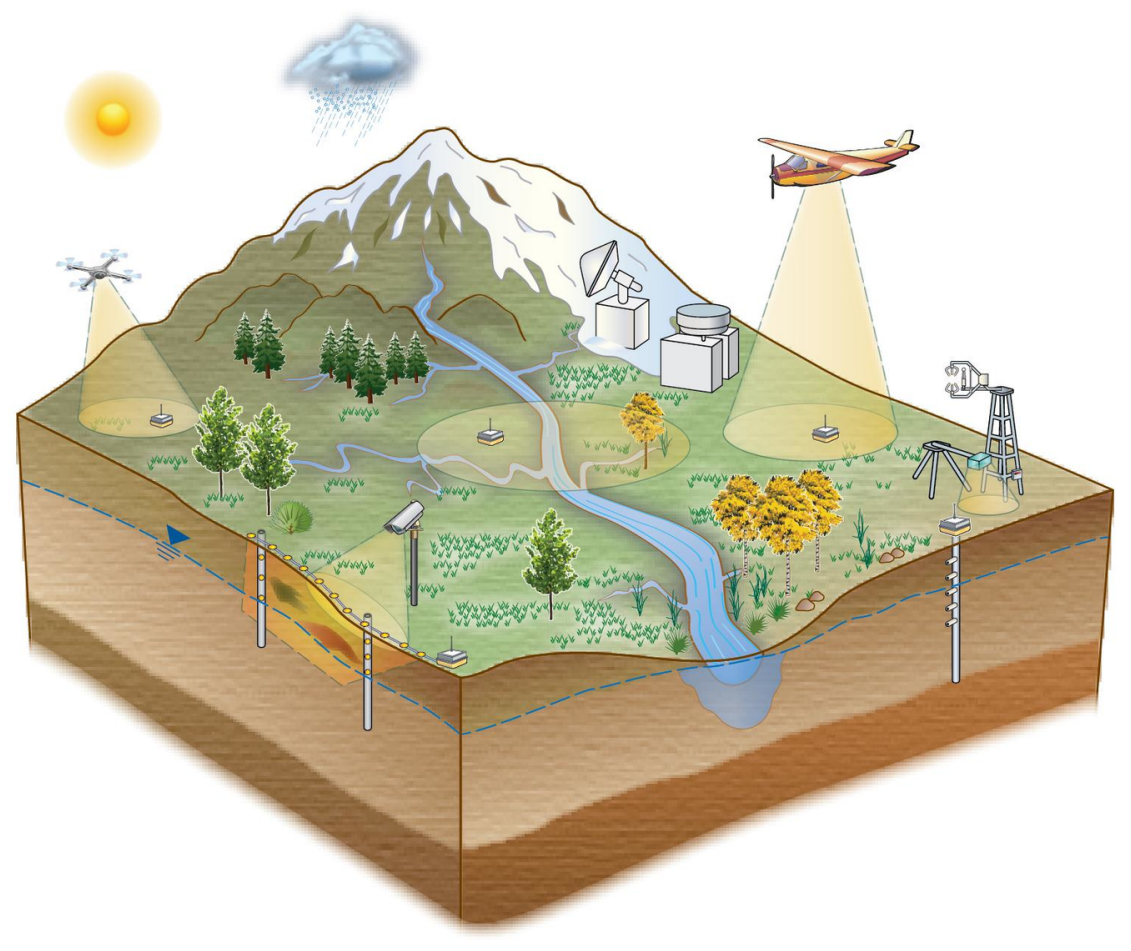

\section{Graphical Abstract (caption not required}

Figure 1a: Map of ER site and measurements of the SFA and some collaborators. The yellow line indicates the East River Community Observatory domain. The red lines indicate the major drainage boundaries of the East River, Washington Gulch (Wash. Gul.), Slate River, and Coal Creek. The blue lines show stream flow lines determined from the National Hydrography Dataset (U.S. Geological Survey, 2001). Measurements by community partners in the Slate River and Redwell basin are not shown. The white box shows the intensively sampled Pumphouse subregion shown in greater detail in Figure 1b. 


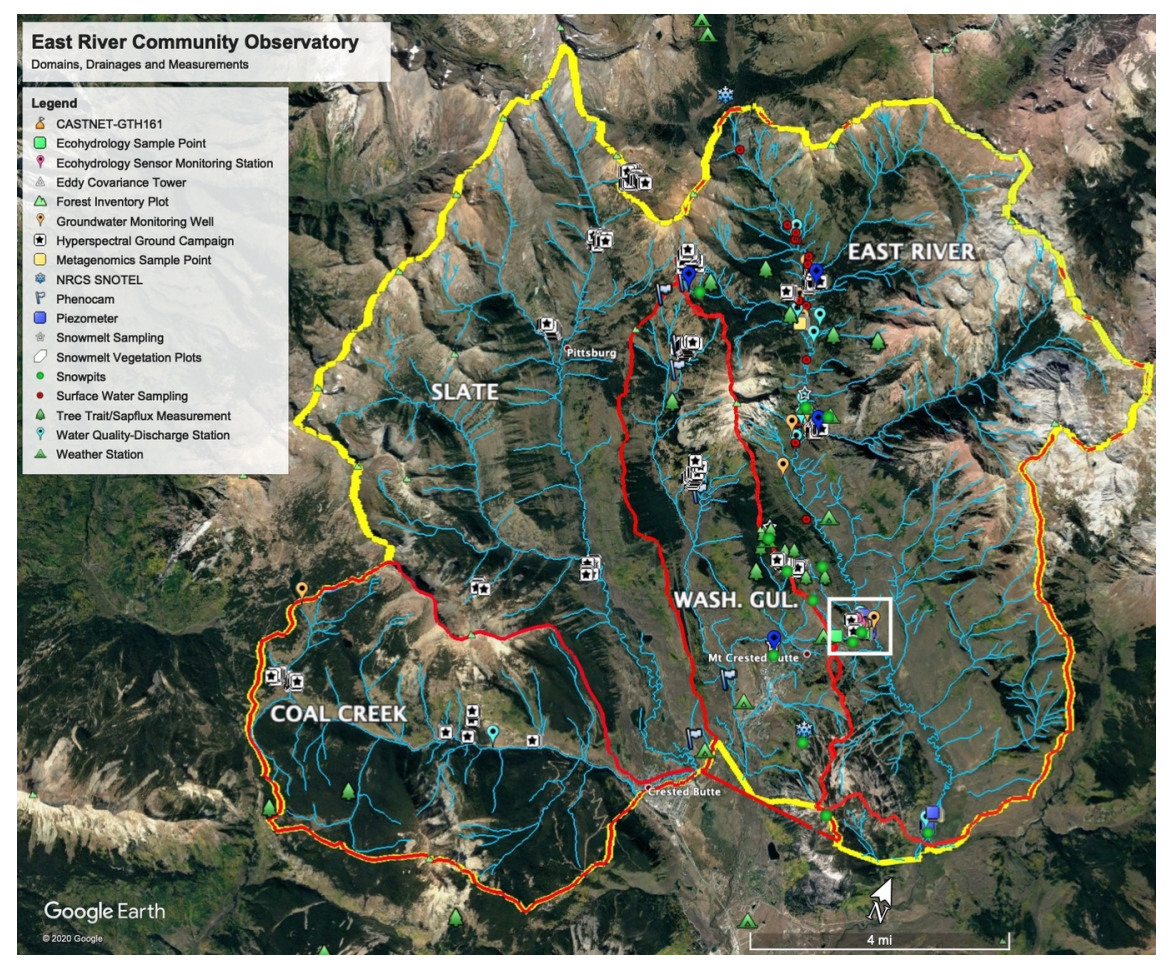

Figure 1b Diverse measurements conducted in the SFA-intensive Pumphouse subregion include a hillslope transect and near the meanders of the East River.

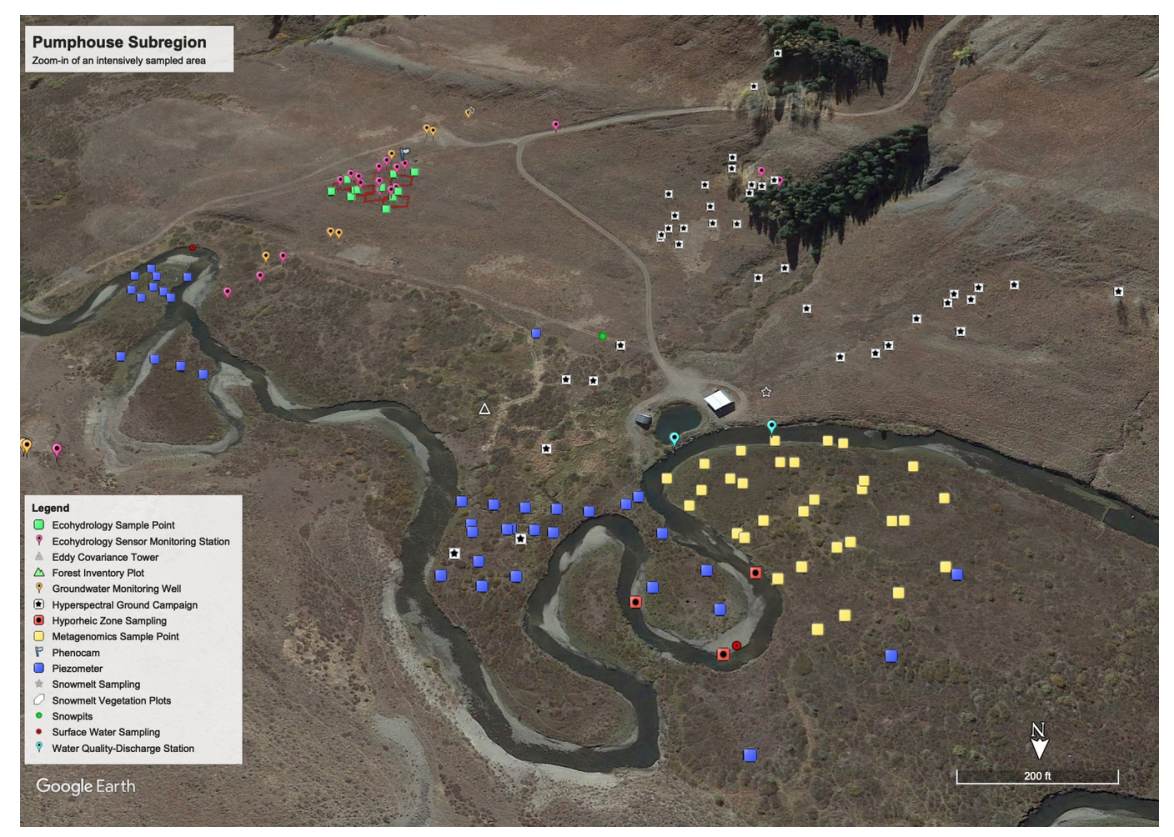

Figure 2. Photographs of some field locations and infrastructure installations in the ER: (A) Hillslope borehole, subsurface water and carbon inventory well (B) Weather station, atmospheric weather sensor in the alpine zone, (C) Pumphouse ISCO, sampler for subsurface discharge and solute flux in the subalpine 
zone, (D) A plot to study impacts of early snowmelt on vegetation at a subalpine location along an elevation gradient
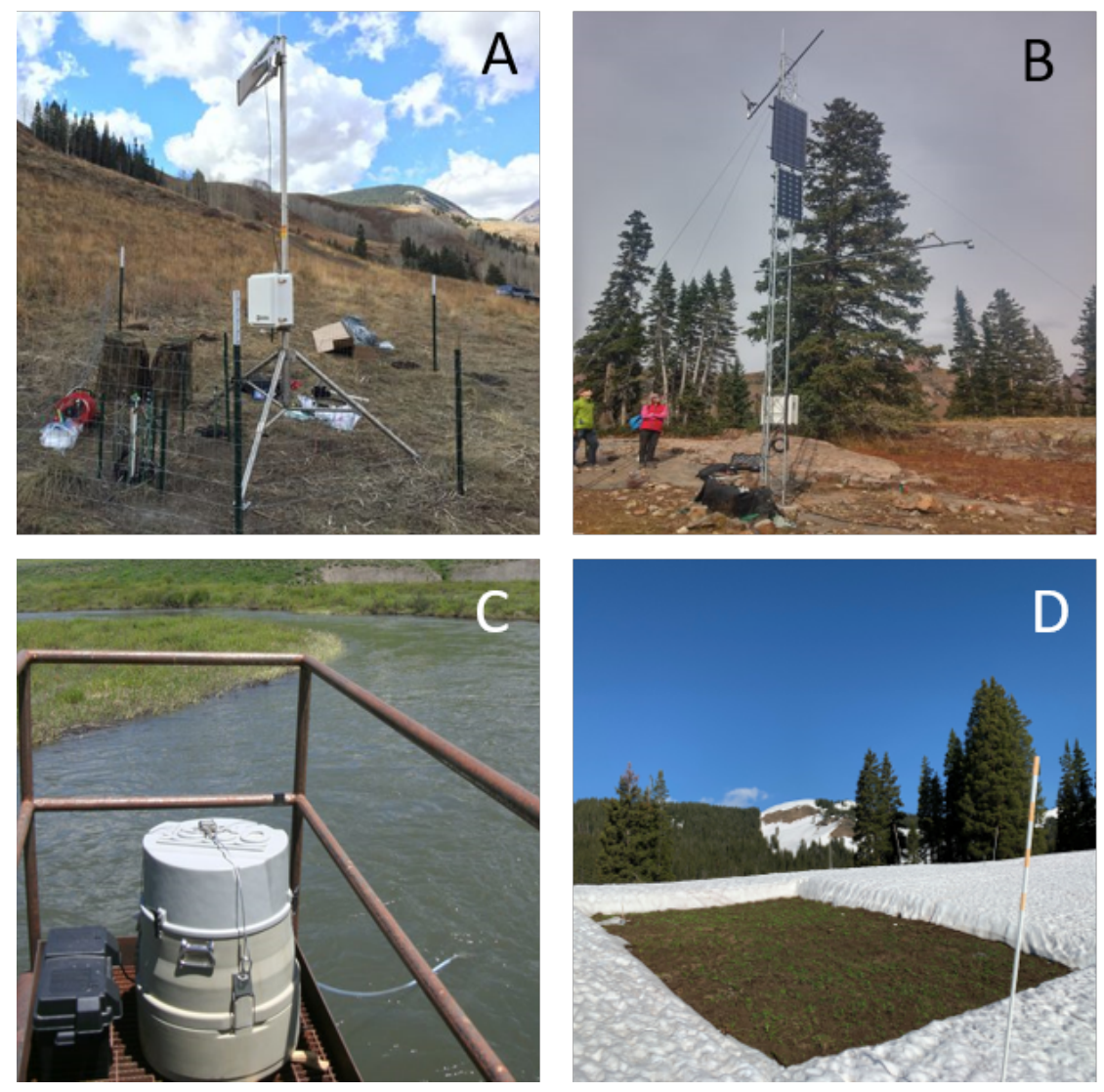

Figure 3. Categories of published data packages from the East River Watershed. The numbers shown in the $\mathrm{X}$ axis represent the number of published data packages with a given data type out of 67 data packages total. Some data packages have data from more than one data type.

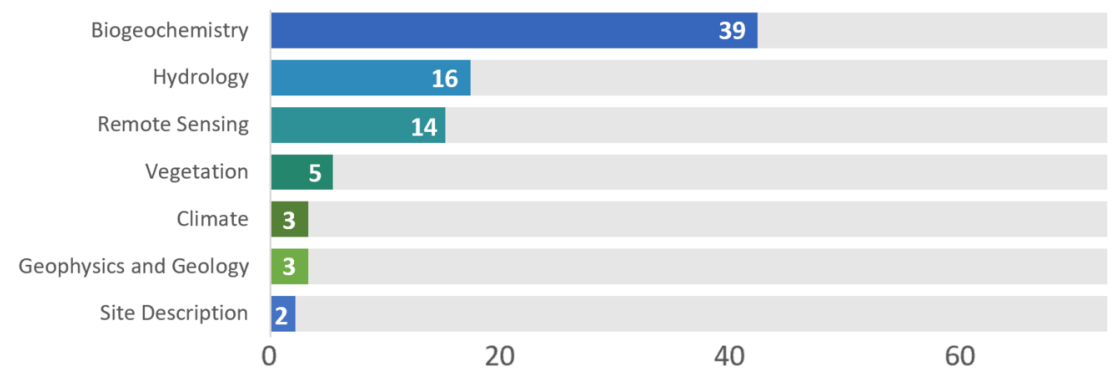

Table 1 . ER Data types, variables, and methods of data collection 
Hydrology

Biogeochemistry

Climate

Vegetation

Geology and Geophysics

Remote Sensing
Evapotranspiration, Groundwater Pressure, Water Table Depths, Groundwater Temperature, Stream Water

Temperature, Stream

Discharge, Soil Moisture, Soil

Temperature, Snow Cover, Snow Chemistry, Snow Density, Water Isotopes, Ecosystem

Respiration, Stream Gas

Exchange Rates, Hydraulic

Conductivity

Surface Water Geochemistry, Groundwater Geochemistry, Isotopes, Anions, Cations, Total

Dissolved Nitrogen, Dissolved

Organic Carbon, Dissolved Inorganic Carbon, Ammonia, Hydrochloride, Dissolved Gas Concentrations, Mineralogy, Metagenomics, Microbial

Biomass, Spectroscopy,

Transcriptomics

Atmospheric deposition, Meteorology, Precipitation,

Energy Fluxes, Heat Flux

Plant growth, Biophysical

Characteristics of Plant Canopy,

Plant Nutrients, Snowmelt Date, Growing Season Microclimate, Leaf Litter Quality, Mass Loss, Sap Flux, Canopy Temperature Soil Electrical Conductivity,

Electrical Resistivity

Tomography, Seismic, Bedrock

Properties, Porosity,

Permeability, Hydraulic Flow,

Soil Thickness, Soil Organic

Carbon

Hyperspectral, Land Surface

Elevation, Normalized

Difference Vegetation Index
ParFlow-CLM, PRISM, SNOTEL, GSFLOW, Groundwater Wells, Snowpits, Pressure Transducers, Acoustic Doppler Current Profiler, Dissolved Gas Sample Collection, Mass Spectrometry

Soil Lysimeter, Nucleic Acids Sequencing, Piezometers, Soil Sensors, Radiation Sensors, Infrared Sensors, Flux devices, MicroMET, MC-ICPMS, TIMS, Chromatography, Laser

Absorbance Spectroscopy

Weather Stations, Microclimate Loggers

Direct physical observations of phenophases and plant canopy characteristics, Sap Flux Sensors, Thermal Cameras,

Sensor Network, Groundwater Well 2-D Spatial Geotiff, Sampling Stations, self-developed model (SCALE)

Ground-penetrating radar, LiDAR, Electromagnetic and Spectroscopic Imaging, Drones

Table 2. 67 public datasets generated by the Watershed Function SFA and collaborating institutions are available in many data repositories. The datasets can be accessed using a digital object identifier (DOI) by appending a prefixhttp://dx.doi.org/DOI. Further details for these data, including descriptions, methods, and author contact information are available on the dataset landing pages. For continued access to newly published datasets, view the East River Watershed portal (https://data.ess-dive.lbl.gov/portals/east-riverwatershed). 
ESS-DIVE (Environmental Systems Science Data Infrastructure for a Virtual Ecosystem): 53 datasets Site Description

Site Description

Biogeochemistry

Biogeochemistry

Biogeochemistry

Biogeochemistry

Biogeochemistry

Biogeochemistry

Biogeochemistry

Biogeochemistry

Biogeochemistry

Biogeochemistry

Biogeochemistry

Biogeochemistry

Biogeochemistry

Biogeochemistry

Biogeochemistry

Biogeochemistry

Biogeochemistry

Biogeochemistry

Biogeochemistry

Biogeochemistry

Biogeochemistry

Biogeochemistry, Climate, Hydrology

Biogeochemistry, Climate, Hydrology

Biogeochemistry, Hydrology

Biogeochemistry, Hydrology

Biogeochemistry

Biogeochemistry, Hydrology

Biogeochemistry, Hydrology

Biogeochemistry, Hydrology

Biogeochemistry, Hydrology

Biogeochemistry, Hydrology, Geology and Geophysics

Biogeochemistry, Remote Sensing

Climate, Remote Sensing, Vegetation

Hydrology

Hydrology

Hydrology

Hydrology

Hydrology

Hydrology

Hydrology

Geophysics and Geology

Geophysics and Geology

Remote Sensing

Remote Sensing

Remote Sensing, Vegetation

Remote Sensing

Remote Sensing

Remote Sensing 
Vegetation

Vegetation

Vegetation

Figshare: 1 dataset

Biogeochemistry

HydroShare: 1 dataset

Hydrogeology, Remote Sensing

NCBI (National Center for Biotechnology Information): 2 datasets

Biogeochemistry

Biogeochemistry

USGS Sciencebase: 6 datasets

Biogeochemistry

Biogeochemistry

Biogeochemistry, Hydrogeology

Biogeochemistry, Hydrogeology

Hydrogeology

Remote Sensing

National Snow and Ice Data Center (NSIDC): 4 datasets

Remote Sensing

Remote Sensing

Remote Sensing

Remote Sensing

Sit

Lea

\section{Fig}

\section{De}

$\mathbf{H y}$
$\mathrm{Da}$

\section{NC}

\section{As}

\section{Us}

+ Datasets generated by the Watershed Function Science Focus Area.

\section{References}

1. Arora, B., Bill, M., Conrad, M., Dong, W., Faybishenko, B., Molins, S., Spycher, N., Steefel, C., Tokunaga, T., Wan, J., \& Williams, K. (2019). Influence of hydrological, biogeochemical and temperature transients on subsurface carbon fluxes in a flood plain environment, Biogeochemistry: Dataset[Data set]. Watershed Function SFA. https://doi.org/10.21952/WTR/1506937

2. Arora, B., Burrus, M., Newcomer, M., Steefel, C., Carroll, R., Dwivedi, D., Dong, W., Williams, K., \& Hubbard, S. (2020). Differential concentration discharge for the upper and lower reaches of the East River Watershed, Colorado [Data set]. Environmental System Science Data Infrastructure for a Virtual Ecosystem; Watershed Function SFA. https://doi.org/10.15485/1657887

3. Arora, B., Dwivedi, D., Hubbard, S., Steefel, C., \& Williams, K. (2019). Identifying geochemical hot moments and their controls on a contaminated river floodplain system using wavelet and entropy approaches, Environmental modelling 83 software: Dataset [Data set]. Watershed Function SFA. https://doi.org/10.21952/WTR/1506938

4. Berkelhammer, M. (2020).Sapflow and xylem water isotopes from Snodgrass Mountain, East River Watershed, Colorado USA [Data set]. Environmental System Science Data Infrastructure for a Virtual Ecosystem; Space and time dynamics of transpiration in the East River watershed: biotic and abiotic controls (DE-SC0019210). https://doi.org/10.15485/1647654

5. Berkelhammer, M., Ritter, F., Williams, K., Carroll, R., Still, C., Winnick, M., Anderson, L., \& Carbone, M. (2020). Conifer water use patterns in the East River Watershed, Colorado US, based on stable water isotopes and cellulose isotopes [Data set]. Space and Time Dynamics of Transpiration in the East River Watershed: Biotic and Abiotic Controls. https://doi.org/10.15485/1596123

6. Bouskill, N. J., Sorensen, P., Conrad, M., Bill, M., Maavara, T., Newman, A., Brodie, E., \& Williams, K. (2020). Natural abundance nitrate isotopes from Rifle and the East River Watershed, Colorado [Data set]. Environmental System Science Data Infrastructure for a Virtual Ecosystem; Watershed Function SFA. https://doi.org/10.15485/1660462 
7. Briggs, M. (2018).Chemical and geophysical data collected along Oh-be-joyful Creek, Gunnison National Forest, Colorado [Data set]. U.S. Geological Survey. https://doi.org/10.5066/F71Z42NF

8. Briggs, M., Dawson, C. B., Holmquist-Johnson, C., Adams, J. D., \& White, E. A. (2019).Thermal infrared, multispectral, and photogrammetric data collected by drone for hydrogeologic analysis of the East River and Coal Creek beaver-impacted corridors near Crested Butte, Colorado[Data set]. U.S. Geological Survey. https://doi.org/10.5066/P9YWSJ2J

9. Briggs, M., Pai, H., Malenda, H., Randell, J., Singha, K., Tyler, S., \& Williams, K. (2017). Fiber-optic distributed temperature data collected along the streambed of the East River, Crested Butte, CO, USA [Data set]. U.S. Geological Survey. https://doi.org/10.5066/F7J9658M

10. Briggs, M., Wang, C., Slater, L., Day, F. D., \& Fosburg, D. (2019). Hydrogeochemical data for the characterization of stream, groundwater, and beaver-induced floodplain exchange in the East River Science Focus Area, Crested Butte, CO [Data set]. U.S. Geological Survey. https://doi.org/10.5066/P9Q1Z1TK

11. Brodrick, P., Goulden, T., \& Chadwick, K. D. (2020). Custom NEON AOP reflectance mosaics and maps of shade masks, canopy water content [Data set]. Environmental System Science Data Infrastructure for a Virtual Ecosystem; Watershed Function SFA. https://doi.org/10.15485/1618131

12. Bryant, S., Briggs, M., Nelson, A., Saup, C., Wilkins, M., Williams, K., \& Sawyer, A. (2019).Estimated Darcy Velocities Using Temperature Time Series for Meander A of East River, Colorado [Data set]. Seasonal controls on dynamic hyporheic zone redox biogeochemistry. https://doi.org/10.15485/1498798

13. Carbone, M. (2019).Depth profiles of soil CO2 Concentrations, soil temperature, and soil moisture (Rocky Mountain Biological Laboratory, Gothic, Colorado, 2011-2016) [Data set]. figshare. https://doi.org/10.6084/M9.FIGSHARE.7834406.V1

14. Carroll, R., Bill, M., Dong, W., \& Williams, K. (2019). Sub-Basin Delineation for the Upper East River, Colorado, United States [Data set]. Watershed Function SFA. https://doi.org/10.21952/WTR/1508403

15. Carroll, R., Deems, J., Niswonger, R., Schumer, R., \& Williams, K. (2019). The Importance of Interflow to Groundwater Recharge in a Snowmelt-Dominated, Alpine Watershed, Geophysical Research Letters: Modeling and Data Package [Data set]. Watershed Function SFA. https://doi.org/10.21952/WTR/1508390

16. Carroll, R., Manning, A., Niswonger, R., Marchetti, D., \& Williams, K. (2019). Copper Creek Baseflow Age Experiment using Environmental Gas Tracers in the East River Watershed, CO [Data set]. Watershed Function SFA. https://doi.org/10.21952/WTR/1572196

17. Carroll, R. W. H., Bearup, L. A., Brown, W., Dong, W., Bill, M., \& Willlams, K. H. (2018). Factors controlling seasonal groundwater and solute flux from snow-dominated basins. Hydrological Processes, 32(14), 2187-2202. https://onlinelibrary.wiley.com/doi/abs/10.1002/hyp.13151

18. Carroll, R., Williams, K., Bill, M., Dong, W., \& Brown, W. (2018). End-Member Mixing Analysis Data Package for the East River Watershed, CO USA [Data set]. Lawrence Berkeley National Laboratory (LBNL), Berkeley, CA (United States). https://doi.org/10.21952/WTR/1465929

19. Chadwick, K. D., Brodrick, P., Grant, K., Henderson, A., Bill, M., Breckheimer, I., Williams, C. F. R., Goulden, T., Falco, N., McCormick, M., Musinsky, J., Pierce, S., Hastings Porro, M., Scott, A., Brodie, E., Hancher, M., Steltzer, H., Wainwright, H., Williams, K., \& Maher, K. (2020). NEON AOP foliar trait maps, maps of model uncertainty estimates, and conifer map, East River, CO 2018 [Data set]. A Multiscale Approach to Modeling Carbon and Nitrogen Cycling within a High Elevation Watershed. https://doi.org/10.15485/1618133

20. Chadwick, K. D., Grant, K., Bill, M., Henderson, A., Scott, A., \& Maher, K. (2020).Site-level Foliar $C, N$, delta13C data from samples collected during field survey associated with NEON AOP survey, East River, CO 2018 [Data set]. A Multiscale Approach to Modeling Carbon and Nitrogen Cycling within a High Elevation Watershed. https://doi.org/10.15485/1631278

21. Chadwick, K. D., Grant, K., Henderson, A., Breckheimer, I., Williams, C. F. R., Falco, N., Chen, J., Henry, H., Khurram, A., Lamb, J., McCormick, M., McOmber, H., Pierce, S., Polussa, A., Hastings Porro, M., Scott, A., Wu Singh, H., Whitney, B., Brodie, E., ... Maher, K. (2020). Locations, 
metadata, and species cover from field sampling survey associated with NEON AOP survey, East River, CO 2018 [Data set]. Watershed Function SFA. https://doi.org/10.15485/1618130

22. Chadwick, K. D., Grant, K., Henderson, A., Scott, A., McCormick, M., Pierce, S., Hastings Porro, M., \& Maher, K. (2020). Leaf mass per area and leaf water content measurements from field survey in association with NEON AOP survey, East River, CO 2018 [Data set]. Environmental System Science Data Infrastructure for a Virtual Ecosystem; A Multiscale Approach to Modeling Carbon and Nitrogen Cycling within a High Elevation Watershed. https://doi.org/10.15485/1618132

23. Chen, J., Dafflon, B., Tran, A., Falco, N., \& Hubbard, S. (2020). Hybrid predictive modeling approach simulated evapotranspiration and ecosystem respiration data[Data set]. Watershed Function SFA. https://doi.org/10.15485/1633810

24. Christensen, J., Brown, S., Dafflon, B., Dong, W., Faybishenko, B., Hubbard, S., Tokunaga, T., Wan, J., \& Williams, K. (2019). Using strontium isotopes to evaluate the spatial variation of groundwater recharge, Science of The Total Environment: Dataset [Data set]. Watershed Function SFA. https://doi.org/10.21952/WTR/1495381

25. Dafflon, B., \& Dwivedi, D. (2020). Groundwater level elevation and temperature at the Lower Montane in the East River Watershed, Colorado [Data set]. Watershed Function SFA. https://doi.org/10.15485/1647040

26. Dana Chadwick, K., Brodrick, P. G., Grant, K., Goulden, T., Henderson, A., Falco, N., Wainwright, H., Williams, K. H., Bill, M., Breckheimer, I., Brodie, E. L., Steltzer, H., Rick Williams, C. F., Blonder, B., Chen, J., Dafflon, B., Damerow, J., Hancher, M., Khurram, A., ... Maher, K. (2020). Integrating airborne remote sensing and field campaigns for ecology and Earth system science. In Methods in Ecology and Evolution. https://doi.org/10.1111/2041-210x.13463

27. Dafflon B ; Malenda H ; Dwivedi D (2020): Groundwater level elevation and temperature across Meander $\mathrm{C}$ at the Lower Montane in the East River Watershed, Colorado. Watershed Function SFA. doi:10.15485/1647041

28. Dawson, C. B., Holmquist-Johnson, C., \& Briggs, M. (2018). Thermal infrared and photogrammetric data collected by small unoccupied aircraft system for hydrogeologic analysis of Oh-be-joyful Creek, Gunnison National Forest, Colorado, August 2017 [Data set]. U.S. Geological Survey. https://doi.org/10.5066/P931G95D

29. Dong, W., Beutler, C., Bouskill, N., Brown, W., Newman, A., Versteeg, R., \& Williams, K. H. (2020). Total Dissolved Nitrogen and Ammonia Data for the East River Watershed, Colorado [Data set]. Watershed Function SFA. https://doi.org/10.15485/1660456

30. Dong, W., Beutler, C., Brown, W., Newman, A., Versteeg, R., \& Williams, K. H. (2020).Dissolved Inorganic Carbon and Dissolved Organic Carbon Data for the East River Watershed, Colorado [Data set]. Environmental System Science Data Infrastructure for a Virtual Ecosystem; Watershed Function SFA. https://doi.org/10.15485/1660459

31. Dong, W., Fox, P., Bhattacharyya, A., Bill, M., \& Nico, P. (2020). Kinetics Data of Iron(II), Manganese(II), Dissolved Organic Carbon and Nitrate from Batch Incubation Experiments Using Hyporheic Sediments from the East River Watershed, Colorado [Data set]. Environmental System Science Data Infrastructure for a Virtual Ecosystem; Watershed Function SFA. https://doi.org/10.15485/1659482

32. Dong W ; Beutler C ; Brown W ; Newman A ; Versteeg R ; Williams K H (2020): Cation Data for the East River Watershed, Colorado. Watershed Function SFA. doi:10.15485/1668055

33. Dwivedi, D. (2019).Geochemical exports to river from the intrameander hyporheic zone under transient hydrologic conditions, Water Resources Research: Dataset [Data set]. Watershed Function SFA. https://doi.org/10.21952/WTR/1506940

34. Dwivedi, D., Steefel, C. I., Arora, B., Newcomer, M., Moulton, J. D., Dafflon, B., Faybishenko, B., Fox, P., Nico, P., Spycher, N., Carroll, R., \& Williams, K. H. (2018). Geochemical Exports to River From the Intrameander Hyporheic Zone Under Transient Hydrologic Conditions: East River Mountainous Watershed, Colorado. Water Resources Research, 54(10), 8456-8477. https://doi.org/10.1029/2018WR023377

35. Dwivedi, D., Steefel, I. C., Arora, B., \& Bisht, G. (2017). Impact of Intra-meander 
Hyporheic Flow on Nitrogen Cycling. Procedia Earth and Planetary Science,17, 404-407. https://doi.org/10.1016/j.proeps.2016.12.102

36. Falco, N., Dafflon, B., Devadoss, J., Shirley, I., Soom, F., Uhlemann, S., \& Wainwright, H. (2020). Time-domain reflectometer survey across the East River Watershed, Colorado [Data set]. Environmental System Science Data Infrastructure for a Virtual Ecosystem; Watershed Function SFA. https://doi.org/10.15485/1648526

37. Fang, Z., Carroll, R. W. H., Schumer, R., Harman, C., Wilusz, D., \& Williams, K. H. (2019). Streamflow partitioning and transit time distribution in snow-dominated basins as a function of climate. Journal of Hydrology, 570, 726-738. https://doi.org/10.1016/j.jhydrol.2019.01.029

38. Fox, P., Anderson, C., Bill, M., Conrad, M., Heckman, K., Keiluweit, M., \& Nico, P. (2019). Geochemical characterization of floodplain sediments from Meander $C$ and $O$ in the East River Watershed, CO, USA [Data set]. Lawrence Berkeley National Laboratory (LBNL), Berkeley, CA (United States). https://doi.org/10.21952/WTR/1572186

39. Gaskill, D. L. (1991). Geologic map of the Gothic quadrangle, Gunnison County, Colorado (No. 1689). https://doi.org/10.3133/gq1689

40. Goulden, T., Hass, B., Brodie, E., Chadwick, K. D., Falco, N., Maher, K., Wainwright, H., \& Williams, K. (2020). NEON AOP Survey of Upper East River CO Watersheds: LAZ Files, LiDAR Surface Elevation, Terrain Elevation, and Canopy Height Rasters [Data set]. Watershed Function SFA. https://doi.org/10.15485/1617203

41. Goulden, T., Hulslander, D., Hass, B., Brodie, E., Chadwick, D. K., Falco, N., Maher, K., Wainwright, H., \& Williams, K. (2020). NEON AOP Imaging Spectroscopy Survey of Upper East River Colorado Watersheds: Raw-Space Radiance and Observational Variable Dataset [Data set]. Watershed Function SFA. https://doi.org/10.15485/1617204

42. Goulden, T., \& Musinsky, J. (2020). Post survey report for AOP Assignable Asset collection of Crested Butte, $C O$ [Data set]. Watershed Function SFA. https://doi.org/10.15485/1617202

43. Hubbard, S., Faybishenko, B., \& Rosemary, C. (2019). The East River, Colorado, Watershed: A Mountainous Community Testbed for Improving Predictive Understanding of Multiscale Hydrological-Biogeochemical Dynamics: Dataset [Data set]. Watershed Function SFA. https://doi.org/10.21952/WTR/1506942

44. Hubbard, S. S., Williams, K. H., Agarwal, D., Banfield, J., Beller, H., Bouskill, N., Brodie, E., Carroll, R., Dafflon, B., Dwivedi, D., Falco, N., Faybishenko, B., Maxwell, R., Nico, P., Steefel, C., Steltzer, H., Tokunaga, T., Tran, P. A., Wainwright, H., \& Varadharajan, C. (2018). The East River, Colorado, Watershed: A Mountainous Community Testbed for Improving Predictive Understanding of Multiscale Hydrological-Biogeochemical Dynamics. Vadose Zone Journal, 17. https://doi.org/10.2136/vzj2018.03.0061

45. Johnson, M. R., Wanty, R. B., Bembenek, A. J., Verplanck, P. L., \& Manning, A. H. (2019).Geochemical analyses of surface- and groundwater and springs from Mount Emmons, near Crested Butte, Colorado, from 1997 to 2017[Data set]. U.S. Geological Survey. https://doi.org/10.5066/P9CQJ0XR

46. Lavy, A., Matheus Carnevali, P. B., Keren, R., Bill, M., Wan, J., Tokunaga, T. K., Williams, K. H., Hubbard, S. S., \& Banfield, J. F. (2020). Taxonomically and metabolically distinct microbial communities with depth and across a hillslope to riparian zone transect (p. 768572). https://doi.org/10.1101/768572

47. Malenda H, S. K. (n.d.).Data from Malenda et al. (2019), Floodplain hydrostratigraphy from sedimentology, geophysics, and remote sensing [Data set]. https://doi.org/10.4211/hs.394a6900a0bd4911b642f9ba94046780

48. Matheus Carnevali, P. B., Lavy, A., Thomas, A. D., Crits-Christoph, A., Diamond, S., Meéheust, R., Olm, M. R., Sharrar, A., Lei, S., Dong, W., Falco, N., Bouskill, N., Newcomer, M., Nico, P., Wainwright, H., Dwivedi, D., Williams, K. H., Hubbard, S., \& Banfield, J. F. (2020). Meanders as a scaling motif for understanding of floodplain soil microbiome and biogeochemical potential at the watershed scale (p. 2020.05.14.086363). https://doi.org/10.1101/2020.05.14.086363

49. Matheus Carnevali, P. B., Schulz, F., Castelle, C. J., Kantor, R. S., Shih, P. M., Sharon, I., Santini, J. 
M., Olm, M. R., Amano, Y., Thomas, B. C., Anantharaman, K., Burstein, D., Becraft, E. D., Stepanauskas, R., Woyke, T., \& Banfield, J. F. (2019). Hydrogen-based metabolism as an ancestral trait in lineages sibling to the Cyanobacteria. Nature Communications, 10(1), 463. https://doi.org/10.1038/s41467-01808246-y

50. Matheus Carnevali, P., Hobson, C., Geller-McGrath, D., Dong, W., Falco, N., Wainwright, H., Lavy, A., Thomas, A., Sharrar, A., Lei, S., Williams, K. H., \& Banfield, J. (2020). Genome-resolved metagenomics and metatranscriptomics of microbial communities in three meander-bound floodplain soils along the East River, Colorado [Data set]. Watershed Function SFA. https://doi.org/10.15485/1631979

51. Nelson, A., Saup, C., Gabor, R., Bryant, S., Harris, K., Williams, K., Wilkins, M., \& Sawyer, A. (2019). Distributed hydrological, chemical, and microbiological measurements around Meander A of East River, Colorado [Data set]. Environmental System Science Data Infrastructure for a Virtual Ecosystem; Seasonal controls on dynamic hyporheic zone redox biogeochemistry. https://doi.org/10.15485/1507800

52. Newcomer, M., Bouskill, N., Wainwright, H., Maavara, T., Arora, B., Woodburn, E., Dwivedi, D., Williams, K., Steefel, C., \& Hubbard, S. (2020). Gap-filled water quality, Normalized Differenced Vegetation Index, total nitrogen (nitrate and ammonia) deposition, and land cover data trends for the Continental United States [Data set]. Watershed Function SFA. https://doi.org/10.15485/1647366

53. Newcomer, M., Raberg, J., Dwivedi, D., Fox, P., Nico, P., Dong, W., \& Steefel, C. (2020).Hyporheic, Floodplain, and Surface Water (on Floodplain and River) Geochemical Datasets, and Shapefiles on Meander $C$ at the East River, Colorado [Data set]. Environmental System Science Data Infrastructure for a Virtual Ecosystem; Watershed Function SFA. https://doi.org/10.15485/1647038

54. Painter, T. (2018a).ASO L4 Lidar Snow Depth 50m UTM Grid, Version 1 [Data set]. https://doi.org/10.5067/STOT5I0U1WVI

55. Painter, T. (2018b).ASO L4 Lidar Snow Water Equivalent 50m UTM Grid, Version 1 [Data set]. https://doi.org/10.5067/M4TUH28NHL4Z

56. Painter, T. H. (2018).ASO L4 Lidar Snow Depth 3m UTM Grid, Version 1 [Data set]. NASA National Snow and Ice Data Center DAAC. https://doi.org/10.5067/KIE9QNVG7HP0

57. Painter, T. H., Berisford, D. F., Boardman, J. W., Bormann, K. J., Deems, J. S., Gehrke, F., Hedrick, A., Joyce, M., Laidlaw, R., Marks, D., Mattmann, C., McGurk, B., Ramirez, P., Richardson, M., Skiles, S. M., Seidel, F. C., \& Winstral, A. (2016). The Airborne Snow Observatory: Fusion of scanning lidar, imaging spectrometer, and physically-based modeling for mapping snow water equivalent and snow albedo. Remote Sensing of Environment, 184, 139-152. https://doi.org/10.1016/j.rse.2016.06.018

58. Painter, T. H., \& Bormann, K. J. (2020). ASO L4 Lidar Point Cloud Digital Terrain Model $3 m$ UTM Grid, Version 1 [Data set]. https://doi.org/10.5067/2EHMWG4IT76O

59. Rosemary, C., \& Williams, K. (2019). Discharge data collected within the East River for the Lawrence Berkeley National Laboratory Watershed Function Science Focus Area (water years 2015-present) [Data set]. Watershed Function SFA. https://doi.org/10.21952/WTR/1495380

60. Rowland, J., \& Stauffer, S. (2020a). Classified channel masks of the East River, Colorado, U.S.A and areas of floodplain erosion and accretion ranging from 1955 to 2015 [Data set]. Environmental System Science Data Infrastructure for a Virtual Ecosystem; Incorporating the Hydrological Controls on Carbon Cycling in Floodplain Ecosystems into Earth System Models (ESMs). https://doi.org/10.15485/1642909

61. Rowland, J., \& Stauffer, S. (2020b). River bank erosion and accretion rates, and planform metrics of the East River, downstream of Gothic Colorado over intervals between 1955 and 2015 [Data set]. Environmental System Science Data Infrastructure for a Virtual Ecosystem; Incorporating the Hydrological Controls on Carbon Cycling in Floodplain Ecosystems into Earth System Models (ESMs). https://doi.org/10.15485/1642910

62. Saup, C., Bryant, S., Nelson, A., Harris, K., Sawyer, A., Christensen, J., Tfaily, M., Williams, K., \& Wilkins, M. (2019). Depth-resolved seasonal porewater chemistry measurements from 3 locations around Meander A of the East River, Colorado [Data set]. Environmental System Science Data Infrastructure for a Virtual Ecosystem; Seasonal controls on dynamic hyporheic zone redox biogeochemistry. https://doi.org/10.15485/1504779 
63. Sitchler, A., Kenwell, A., Prugue, R., \& Spear, J. (2019). Using geochemical indicators to distinguish high biogeochemical activity in floodplain soils and sediments, Science of the Total Environment: Dataset [Data set]. Watershed Function SFA. https://doi.org/10.21952/WTR/1506944

64. Sorensen, P., Brodie, E., Beller, H., Wang, S., Bill, M., \& Bouskill, N. (2019a).Metadata for Soil Nitrogen, Microbial Biomass, and Bacterial and Fungal Communities from the East River Watershed, Colorado collected in 2016-2017 [Data set]. Lawrence Berkeley National Laboratory (LBNL), Berkeley, CA (United States). https://doi.org/10.21952/WTR/1573029

65. Sorensen, P., Brodie, E., Beller, H., Wang, S., Bill, M., \& Bouskill, N. (2019b). Soil Nitrogen, Water Content, Microbial Biomass, and Archaeal, Bacterial and Fungal Communities from the East River Watershed, Colorado collected in 2016-2017 [Data set]. https://www.osti.gov/biblio/1577267

66. Sorensen, P. O., Beller, H. R., Bill, M., Bouskill, N. J., Hubbard, S. S., Karaoz, U., Polussa, A., Steltzer, H., Wang, S., Williams, K. H., Wu, Y., \& Brodie, E. L. (2020). The Snowmelt Niche Differentiates Three Microbial Life Strategies That Influence Soil Nitrogen Availability During and After Winter. Frontiers in Microbiology, 11, 871. https://doi.org/10.3389/fmicb.2020.00871

67. Stegen, J., Brodie, E., Wrighton, K., Bayer, P., Lesmes, D., Emani, S., \& Moerman, J. (2019).Open Watershed Science by Design: Leveraging Distributed Research Networks to Understand Watershed Systems: Workshop Report. https://doi.org/10.2172/1616528

68. Sutfin, N., \& Rowland, J. (2019a). Annual floodplain sediment deposition recorded using feldspar clay marker horizons along the East River, Colorado, 2015-2017 [Data set]. Environmental System Science Data Infrastructure for a Virtual Ecosystem; Incorporating the Hydrological Controls on Carbon Cycling in Floodplain Ecosystems into Earth System Models (ESMs). https://doi.org/10.15485/1577279

69. Sutfin, N., \& Rowland, J. (2019b). Depth and elevation of floodplain fine sediment along the East River near Crested Butte, Colorado measured in 2016 and 2017[Data set]. Environmental System Science Data Infrastructure for a Virtual Ecosystem; Incorporating the Hydrological Controls on Carbon Cycling in Floodplain Ecosystems into Earth System Models (ESMs). https://doi.org/10.15485/1574502

70. Tokunaga, T., Carroll, R., Conrad, M., Tran, A., Wan, J., \& Williams, K. (2019). Hillslope subsurface flow and transport data for the PLM transect in East River, Colorado [Data set]. Watershed Function SFA. https://doi.org/10.21952/WTR/1506941

71. Uhlemann, S., Carr, B., Dafflon, B., \& Williams, K. (2020). Geophysical borehole logging data of wells ER-GLS1, ER-GUM1, ER-PLM7, and ER-PLM8 at the East River Watershed, Colorado [Data set]. Watershed Function SFA. https://doi.org/10.15485/1650355

72. U.S. Geological Survey. (2001). National Hydrography Dataset (NHD) [Data set]. https://doi.org/10.3133/70046927

73. Varadharajan, C., Agarwal, D. A., Brown, W., Burrus, M., Carroll, R. W. H., Christianson, D. S., Dafflon, B., Dwivedi, D., Enquist, B. J., Faybishenko, B., \& Others. (2019). Challenges in Building an End-to-End System for Acquisition, Management, and Integration of Diverse Data From Sensor Networks in Watersheds: Lessons From a Mountainous Community Observatory in East River, Colorado. IEEE Access, 7, 182796-182813. https://ieeexplore.ieee.org/abstract/document/8924700/

74. Varadharajan C ; Kakalia Z ; Versteeg R ; Christianson D ; Henderson M ; Williams K ; Agarwal D (2020): Location Identifiers, Metadata, and Map for Field Measurements at the East River Watershed, Colorado, USA. Watershed Function SFA. doi:10.15485/1660962

75. Wainwright, H., \& Williams, K. (2017). LiDAR collection in August 2015 over the East River Watershed, Colorado, USA [Data set]. Watershed Function SFA. https://doi.org/10.21952/WTR/1412542

76. Wan, J., Tokunaga, T. K., Williams, K. H., Brown, W., Dong, W., Henderson, A. N., Newman, A. M., \& Hubbard, S. S. (2019). Predicting sedimentary bedrock subsurface weathering fronts and weathering rates: Dataset [Data set]. Watershed Function SFA. https://doi.org/10.15485/1601290

77. Wan, J., Tokunaga, T. K., Williams, K. H., Dong, W., Brown, W., Henderson, A. N., Newman, A. W., \& Hubbard, S. S. (2019). Predicting sedimentary bedrock subsurface weathering fronts and weathering rates. Scientific Reports,9(1), 17198. https://doi.org/10.1038/s41598-019-53205-2

78. Williams K ; Beutler C ; Brown W ; Henderson A ; Newman A (2020): Anion Data for the East River Watershed, Colorado. Watershed Function SFA. doi:10.15485/1668054 
79. Williams K ; Beutler C ; Bill M ; Brown W ; Carroll R ; Henderson A ; Newman A (2020): Stable Water Isotope Data for the East River Watershed, Colorado. Watershed Function SFA. doi:10.15485/1668053

80. Winnick, M., Lawrence, C., \& Maher, K. (2020). Soil Environmental Conditions in the East River Watershed, $C O$ [Data set]. Environmental System Science Data Infrastructure for a Virtual Ecosystem; Development of a molecularly informed biogeochemical framework for reactive transport modeling of subsurface carbon inventories, transformations and fluxes. https://doi.org/10.15485/1660455

81. Zaremba-Niedzwiedzka, K., Caceres, E. F., Saw, J. H., Bäckström, D., Juzokaite, L., Vancaester, E., Seitz, K. W., Anantharaman, K., Starnawski, P., Kjeldsen, K. U., Stott, M. B., Nunoura, T., Banfield, J. F., Schramm, A., Baker, B. J., Spang, A., \& Ettema, T. J. G. (2017). Asgard archaea illuminate the origin of eukaryotic cellular complexity. Nature,541(7637), 353-358. https://doi.org/10.1038/nature21031

82. Zhi, W., Li, L., Dong, W., Brown, W., Kaye, J., Steefel, C., \& Williams, K. (2019).Distinct Source Water Chemistry Shapes Contrasting Concentration Discharge Patterns, Water Resources Research: Dataset [Data set]. Watershed Function Scientific Focus Area. https://doi.org/10.21952/WTR/1528928

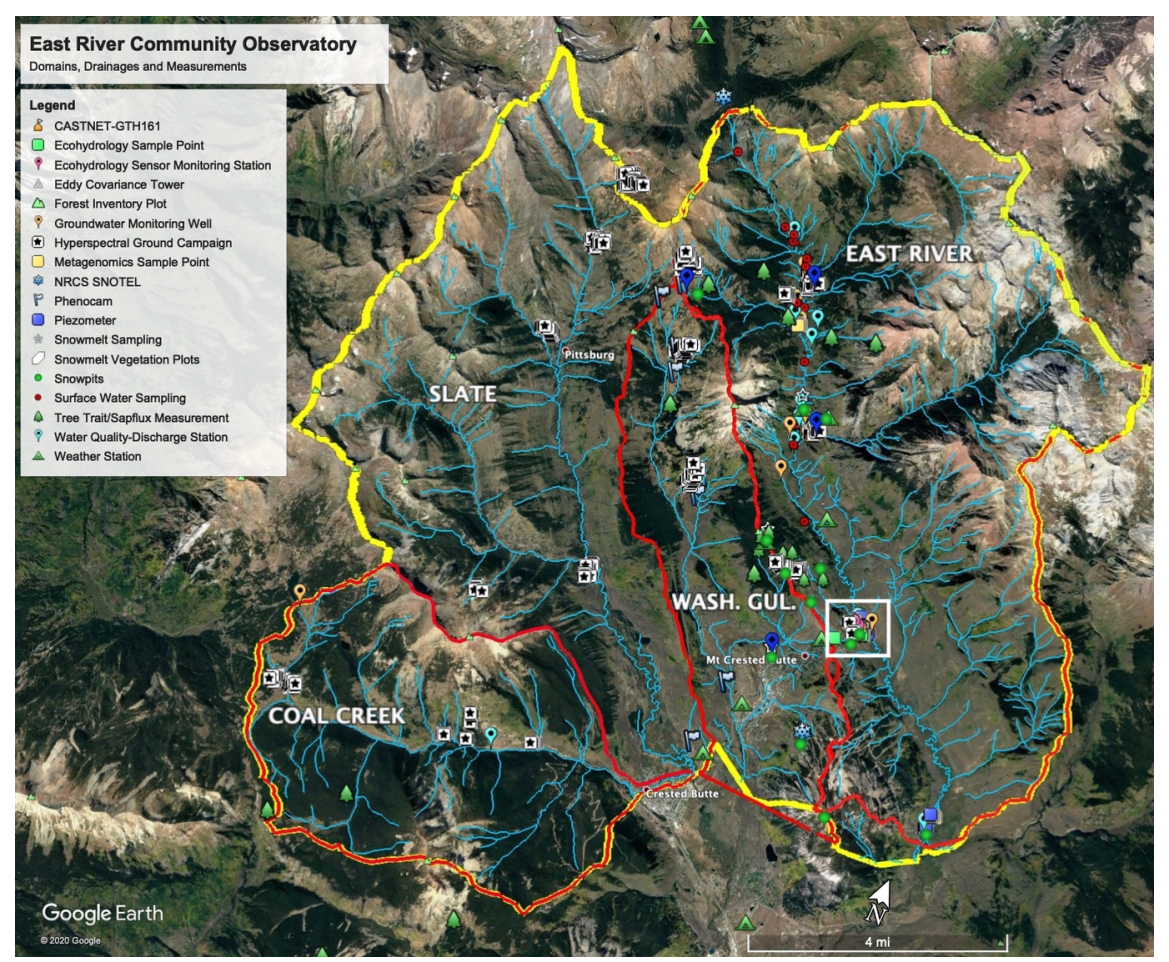



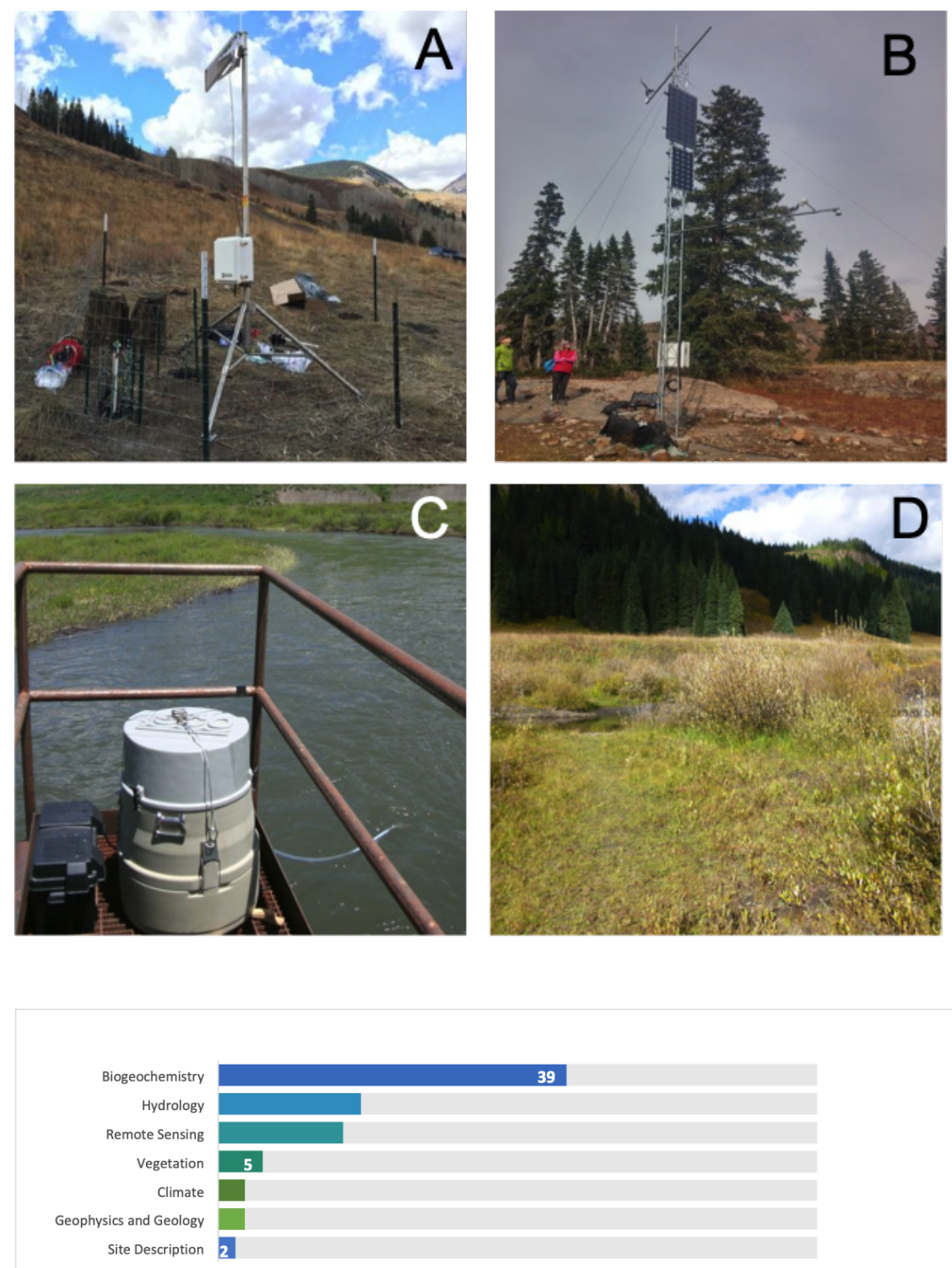